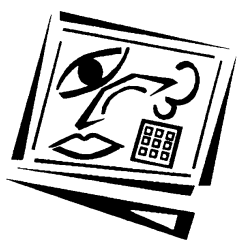

\title{
Smartphones give you wings: Pedagogical affordances of mobile Web 2.0
}

\author{
Thomas Cochrane and Roger Bateman
} Unitec New Zealand

\author{
An Outstanding Paper Award recipient, ascilite Auckland 2009 Conference
}

\begin{abstract}
Built on the foundation of four years of research and implementation of mobile learning projects (m-learning), this paper provides an overview of the potential of the integration of mobile Web 2.0 tools (based around smartphones) to facilitate social constructivist pedagogies and engage students in tertiary education. Pedagogical affordances of mobile Web 2.0 tools are evaluated, and student usage and feedback is outlined via an interactive multimedia timeline (using YouTube videos) illustrating how these mobile Web 2.0 pedagogical affordances have transformed pedagogy and facilitated student engagement in a variety of course contexts. A rubric for evaluating appropriate smartphone choices is provided, and a model for implementing mobile Web 2.0 pedagogical integration is presented.
\end{abstract}

\section{Introduction}

M-learning is a rapidly developing paradigm driven by exponential changes in the capabilities of mobile technologies and their integration with Web 2.0 social software. Worldwide marketshare of mobile devices is increasing, eclipsing traditional computer ownership. There are over four billion cellphone users worldwide, while there are only around 800 million computer owners. The smartphone market is set to exceed computer users by 2014 when the smartphone market is expected to reach $30 \%$ of the worldwide cellphone market (Hendery, 2009). When this research project began in 2006, neither the iPhone or low cost 3G netbooks existed, the iTunes Store was unavailable in New Zealand, wireless connectivity speeds were limited to first generation 3G (UMTS or CDMA) with limited coverage available, and wifi was limited to $54 \mathrm{Mb} / \mathrm{s}$. The mobile Internet was limited to WAP enabled sites, Google's mobile suite of tools were immature, media-rich smartphone applications required Java implementation across a wide range of different interfaces, and Prensky's assertion for education: "What can you learn from a cell phone? Almost anything!" (2005) appeared to many educators to be a hopeful fairytale.

Now in 2009, over five billion songs and 1.5 billion iPhone applications (within a year of the opening of the iTunes App Store, with a catalogue of over 65,000 applications available) have been downloaded from the iTunes store. The majority of our students now own at least a cameraphone capable of mobile blogging, recording and uploading video to YouTube, email, and browsing the Internet. Smartphones have matured into feature-rich miniature multimedia computers, including features such as HSPA connectivity (3.6 Mb/s and higher wireless mobile broadband connectivity), built in virtual or physical keyboards for easy text entry, a high resolution digital still 
and video camera, a GPS, high capacity memory storage (now $8 \mathrm{~Gb}$ and higher is standard), high resolution touchscreen user interfaces, and a wide variety of preinstalled and downloadable applications that integrate with Web 2.0 social software.

The research overviewed herein implements and investigates the application of wireless mobile devices (WMDs) in a variety of tertiary education courses within New Zealand. The first author is part of Te Puno Ako (formerly the Centre for Teaching and Learning Innovation team) at Unitec, and as such is ideally situated at Unitec to promote and research the potential of WMDs to enhance the delivery of courses and student learning. The research covers a series of mobile Web 2.0 project implementations within courses from different schools at Unitec between 2007 and 2009 , with the aim of informing an institutional m-learning strategy. The project developed an intentional community of practice (COP) model for supporting new technology integration, pedagogical development, and institutional change. Beginning with a small selection of early adopter trials, the results of the research are now informing a wider integration of wireless mobile computing. Trials and pilots were established to establish support for the concept from tutors and students at Unitec. The initial proof of concept trials have lead to the integration of the m-learning project model into the newly developed institutional e-learning strategy. The trials played an important role in exploring the skills and confidence of academic staff in utilising the technology before full implementation within their courses. The research follows a journey of discovery for the key participants (including the researcher and the lecturers involved), that has been recorded in over thirty research outputs during the past four years.

\section{Background}

\section{Why m-learning?}

The key drivers are the enhancement of teaching and learning, facilitating student centred social constructivist pedagogies. The goal is the establishment of social constructivism (in its various emergent forms) as the strategic pedagogy underpinning a tertiary institution's teaching and learning environment. The growing popularity of a relatively new social learning management system (LMS - Moodle) and the availability of interactive, easy to use Web 2.0 social software tools make this strategy timely. Equitable access to these tools is critical. Therefore the provision of some form of appropriate wireless mobile computing device for all students and teaching staff is required, which may take the form of either a netbook, a laptop, or a smartphone depending upon what is appropriate for each course of study.

Key benefits of m-learning for tertiary education include:

- Exploring innovative teaching and learning practices.

- Enabling the embodiment of 'authentic learning' - i.e. facilitating anywhere, anytime, student centred learning.

- Engaging students with the affordances of mobile Web 2.0 technologies: connectivity, mobility, geolocation, social networking, personal podcasting and vodcasting, etc...

- Bridging the 'digital divide' by providing access to learning contexts and user content creation tools that are affordable and increasingly owned by students.

- Moving from a model of fixed, dedicated general computing to a mobile, wireless computing paradigm that turns any space into a potential learning space. 


\section{Mobile Web 2.0}

M-learning (mobile learning) technologies provide the ability to engage in learning conversations between students and lecturers, between student peers, students and subject experts, and students and authentic environments within any context. It is the potential for mobile learning to bridge pedagogically designed learning contexts, facilitate learner generated contexts, and content (both personal and collaborative), while providing personalisation and ubiquitous social connectedness, that sets it apart from more traditional learning environments. Mobile learning, as defined in this paper, involves the use of wireless enabled, mobile digital devices (wireless mobile devices or WMDs) within and between pedagogically designed learning environments or contexts. Mobile Web 2.0 tools are used to facilitate this (Web 2.0 services that are formatted for use with mobile devices). Web 2.0 (O'Reilly, 2005), or 'social software' tools, share many synergies with social constructivist learning pedagogies. Many educators have harnessed Web 2.0 tools for creating engaging, student centred learning environments. This appropriation of Web 2.0 tools within a social constructivist pedagogy facilitates what has been termed "pedagogy 2.0" (McLoughlin \& Lee, 2008). From an activity theory perspective, WMDs are the tools that mediate a wide range of learning activities and facilitate collaborative learning environments (Uden, 2007).

\section{The research project}

The research project involved a series of reflective action research projects (2007 to 2009) using WMDs to harness the potential of current and emerging social constructivist e-learning tools. The educational contexts included: the Diploma of Landscape Design, Bachelor of Product design, Diploma of Contemporary Music, Bachelor of Architecture, and Bachelor of Performing Arts. An explicit social constructivist pedagogy underpins each project. This research project is interested in appropriating the benefits of Web 2.0 and pedagogy 2.0 anywhere anytime using mobile Web 2.0 and wireless mobile devices (or WMDs), in particular WiFi (wireless ethernet) and 3G (third generation mobile 'broadband') enabled smartphones, and 3G enabled netbooks. Figure 1 below is a concept map developed to illustrate graphically the links between multiple learning contexts, and the Web 2.0 technologies that the smartphones afford. The research also provides a unique window into the journey of the participants and the researcher via authentic video reflections captured along the course of the research, and made available on YouTube and various Web 2.0 social software sites. These provide rich media snapshots recording the story of the key participants longitudinally throughout the research.

\section{Methodology}

\section{M-learning projects 2006 to 2009}

The research methodology is outlined in detail in previous papers (Cochrane, 2006, 2007, 2008); included here is a brief summary to situate this paper within the overall research project. The research projects were collaborative projects between the researcher (as the technology steward), the course lecturers and their students. Research funding was gained to supply participants (lecturers and students) with an appropriate current smartphone for each project to use as their own throughout the project. Lecturers participated in a regular community of practice to learn the affordances of mobile Web 2.0 technologies for their course, and then implemented 
these with volunteering students from their courses. Different funding models for paying for $3 G$ data costs were experimented with, but all smartphones included wifi connectivity for free Internet connectivity while on campus. Pre-trial surveys captured the participants previous mobile Web 2.0 experience. Lecturers and students then attended a weekly 'community of practice' (COP) throughout the duration of the project investigating and supporting the integration of mobile web 2.0 tools into their courses. Participant feedback was captured via their online Web 2.0 sites, including a blog/e-portfolio. A post-trial survey and focus group discussion were also used to capture participant feedback. Each project informed the design of subsequent projects.

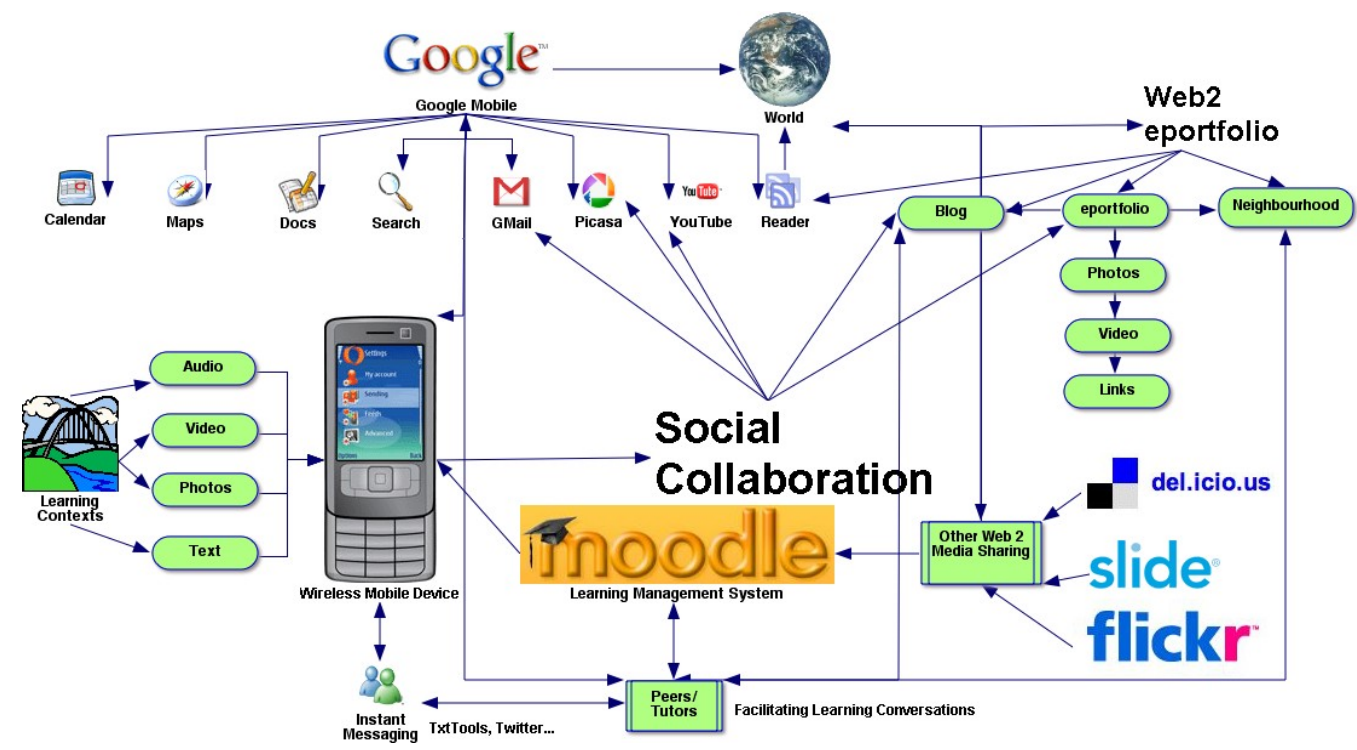

Figure 1: Mobile Web 2.0 concept map

The wider project research questions are listed below. Question 4 is the main focus of this paper:

1. What are the key factors in integrating wireless mobile devices (WMDs) within tertiary education courses?

2. What challenges/advantages to established pedagogies do these disruptive technologies present?

3. To what extent can these WMDs be utilised to support learner interactivity, collaboration, communication, reflection and interest, and thus provide pedagogically rich learning environments that engage and motivate the learner?

4. To what extent can WMDs be used to harness the potential of current and emerging social constructivist e-learning tools?

\section{Pedagogical affordances of mobile Web 2.0}

A wide variety of applications of the WMDs were investigated throughout the various projects, some with more success than others. Experience and feedback from participants has shown that we should focus on the affordances of WMDs that are most suitable for the small screens and slower text entry, as well as those affordances that are unique to WMDs (e.g. the built in geotagging, media recording capabilities, 
and communications tools). Several of these affordances are explored in the following section and summarised in Table 1 below. The built in microphone of smartphones can be used to record audio and then upload that audio file to an online blog or other Web 2.0 site that supports audio. This uploaded audio recording could then form the basis of an ongoing podcast show. Podcasting is a popular form of audio recording that has an associated RSS feed for subscribing to new audio recordings. Students could record themselves reflecting or reporting on their progress in an assignment or project, or they could record an interview with an expert in the field, etc. An example of an enhanced audio podcasting service is Audioboo [http://www.audioboo.com], which is designed specifically for recording, uploading and sharing audio recordings from the iPhone. Audioboo was used to record environmental sounds as a project within the Diploma of Contemporary Music at Unitec in 2009.

Table 1: Affordances of smartphones mapped to social constructivist activities for 2009

\begin{tabular}{|c|c|c|c|}
\hline Activity & Overview & Examples & Pedagogy \\
\hline $\begin{array}{l}\text { Video } \\
\text { streaming }\end{array}$ & $\begin{array}{l}\text { Record and share live } \\
\text { events }\end{array}$ & $\begin{array}{l}\text { Flixwagon, Qik } \\
\text { http://www.qik.com/ }\end{array}$ & $\begin{array}{l}\text { Real time event, data } \\
\text { and resource capturing } \\
\text { and collaboration. }\end{array}$ \\
\hline $\begin{array}{l}\text { Geo } \\
\text { tagging }\end{array}$ & $\begin{array}{l}\text { Geo-tag original } \\
\text { photos, geo-locate } \\
\text { events on Google Maps }\end{array}$ & $\begin{array}{l}\text { Flickr, Twitter, Google Maps } \\
\text { http:/ / tinyurl.com/5a85yh }\end{array}$ & $\begin{array}{l}\text { Enable rich data } \\
\text { sharing. }\end{array}$ \\
\hline $\begin{array}{l}\text { Micro- } \\
\text { blogging }\end{array}$ & $\begin{array}{l}\text { Post short updates } \\
\text { and collaborate using } \\
\text { micro-blogging } \\
\text { services }\end{array}$ & $\begin{array}{l}\text { Twitter } \\
\text { http:/ / tinyurl.com/2j5sz3 }\end{array}$ & $\begin{array}{l}\text { Asynchronous } \\
\text { communication, } \\
\text { collaboration and } \\
\text { support. }\end{array}$ \\
\hline $\begin{array}{l}\text { Txt notific- } \\
\text { ations }\end{array}$ & $\begin{array}{l}\text { Course notices and } \\
\text { support }\end{array}$ & $\begin{array}{l}\text { Txttools plugin for Moodle and } \\
\text { Blackboard } \\
\text { txt and twitter polls: } \\
\text { http: / / www.polleverywhere.com/ } \\
\text { http: / / twitter.polldaddy.com } \\
\text { http:/ / twtpoll.com/ }\end{array}$ & $\begin{array}{l}\text { Scaffolding, learning } \\
\text { and administrative } \\
\text { support }\end{array}$ \\
\hline $\begin{array}{l}\text { Direct } \\
\text { image and } \\
\text { video } \\
\text { blogging }\end{array}$ & $\begin{array}{l}\text { Capture and upload } \\
\text { images and video of } \\
\text { ideas and events }\end{array}$ & Flickr, YouTube, Vox & $\begin{array}{l}\text { Student journals, } \\
\text { eportfolios, } \\
\text { presentations, peer and } \\
\text { lecturer critique. }\end{array}$ \\
\hline $\begin{array}{l}\text { Mobile } \\
\text { codes }\end{array}$ & $\begin{array}{l}\text { 2D codes scanned by } \\
\text { cameraphone to } \\
\text { reveal URL, text, etc. }\end{array}$ & $\begin{array}{l}\text { QR Codes, Datamatrix 2D Codes } \\
\text { http:/ / tinyurl.com/af2u6d }\end{array}$ & $\begin{array}{l}\text { Situated Learning - } \\
\text { providing context } \\
\text { linking }\end{array}$ \\
\hline $\begin{array}{l}\text { Enhanced } \\
\text { student } \\
\text { podcasts }\end{array}$ & $\begin{array}{l}\text { Remote recording of } \\
\text { audio, tagged with } \\
\text { GPS and images, etc. }\end{array}$ & AudioBoo & $\begin{array}{l}\text { Situated and } \\
\text { collaborative learning } \\
\text { - providing context } \\
\text { linking }\end{array}$ \\
\hline $\begin{array}{l}\text { Social } \\
\text { networking }\end{array}$ & $\begin{array}{l}\text { Collaborate in groups } \\
\text { using social } \\
\text { networking tools }\end{array}$ & $\begin{array}{l}\text { Vox groups, Ning, peer and lecturer } \\
\text { comments on blog and media posts } \\
\text { http:/ / tinyurl.com/4uz6rj }\end{array}$ & $\begin{array}{l}\text { Formative peer and } \\
\text { lecturer feedback. }\end{array}$ \\
\hline
\end{tabular}

Almost all smartphones now include a built in camera that is capable of capturing still images and video. Most smartphones also include a built in GPS (Global Positioning Service) that works via satellites to provide longitude and latitude information for geotagging and geo-location. This facilitates geo-tagging original photos, and the ability to geo-locate events on Google Maps, adding a location dimension to captured images and video. Web 2.0 services that support geo-tagged photos include Flickr and Picasaweb. 
Mobile codes are two-dimensional codes similar to bar codes that allow a user to encrypt information such as a URL, a paragraph of text, GPS coordinates, or a business card. This code is then decrypted using a smartphone's built in camera via a compatible mobile code application. Applications include sharing of announcements and course links with students, and creating engaging fun discovery activities.

The built in camera on smartphones can record video and audio at up to almost DVD quality. This facilitates students recording events, interviews, and reflections with a visual dimension, and sharing these online via a variety of mobile friendly video sites such as YouTube. Video streaming applications such as Qik and Flixwagon allow real time sharing of video directly from smartphones to these web based services. Qik and Flixwagon then archive the video stream for later viewing, sharing and commenting. Additionally, video streaming sites integrate with other mobile Web 2.0 technologies such as Twitter - creating an automatic announcement on Twitter regarding a live video stream that a student's Twitter followers can then watch in almost real time. Qik and Flixwagon also feature the ability to forward video streams to a user's YouTube account for sharing on that service as well. Additionally, Qik and Flixwagon also support the association of geo-location data with video streams, providing a Google Maps link to the actual location of the recorded event.

Microblogging is another mobile friendly form of social networking. Microblogging is a cross between SMS texting, blogging, and instant messaging. Microblogging is an asynchronous, collaborative communication technology, suited to use on mobile devices. The most popular microblogging service is currently Twitter.

Vox and Ning are examples of blog/e-portfolio/social networking sites that support direct uploads from mobile devices via email, and provide small-screen formatted versions of their sites for mobile viewing. These sites facilitate collaborative group work, without the additional (often distracting) 'features' of sites such as Myspace or Facebook.

\section{Results}

Student feedback from the m-learning projects clearly showed that the choice of smartphone was critically important in the acceptance of its use. This is a function of both the social acceptance (social construction) of a smartphone, and the smartphone's ability to enhance the specific requirements of a particular course's focus. In response to this a smartphone evaluation rubric was developed for choosing an appropriate smartphone for each of the 2009 projects. The rubric was used for comparative rating of several current (2009) and soon to be available smartphones according to their match with sixteen chosen affordances for m-learning and mobile Web 2.0. An example rubric evaluation is given below in Table 2. This uses a rating via 'unweighted' affordances - i.e. for some projects particular affordances will be more important than others, and therefore should be given higher than equal rating factors (e.g. video recording capability may be the most important for a particular project). Finally, the cost of the smartphone may be a key limitation, which will effectively narrow the list of choices available. The ranking of affordances (Ranked 0 (not available), 1 poor, 2 good, 3 excellent) is of course relatively subjective, but is based on the experiences of previous projects. 
Table 2: Rubric for ranking the affordances of example smartphones for mobile web 2.0.

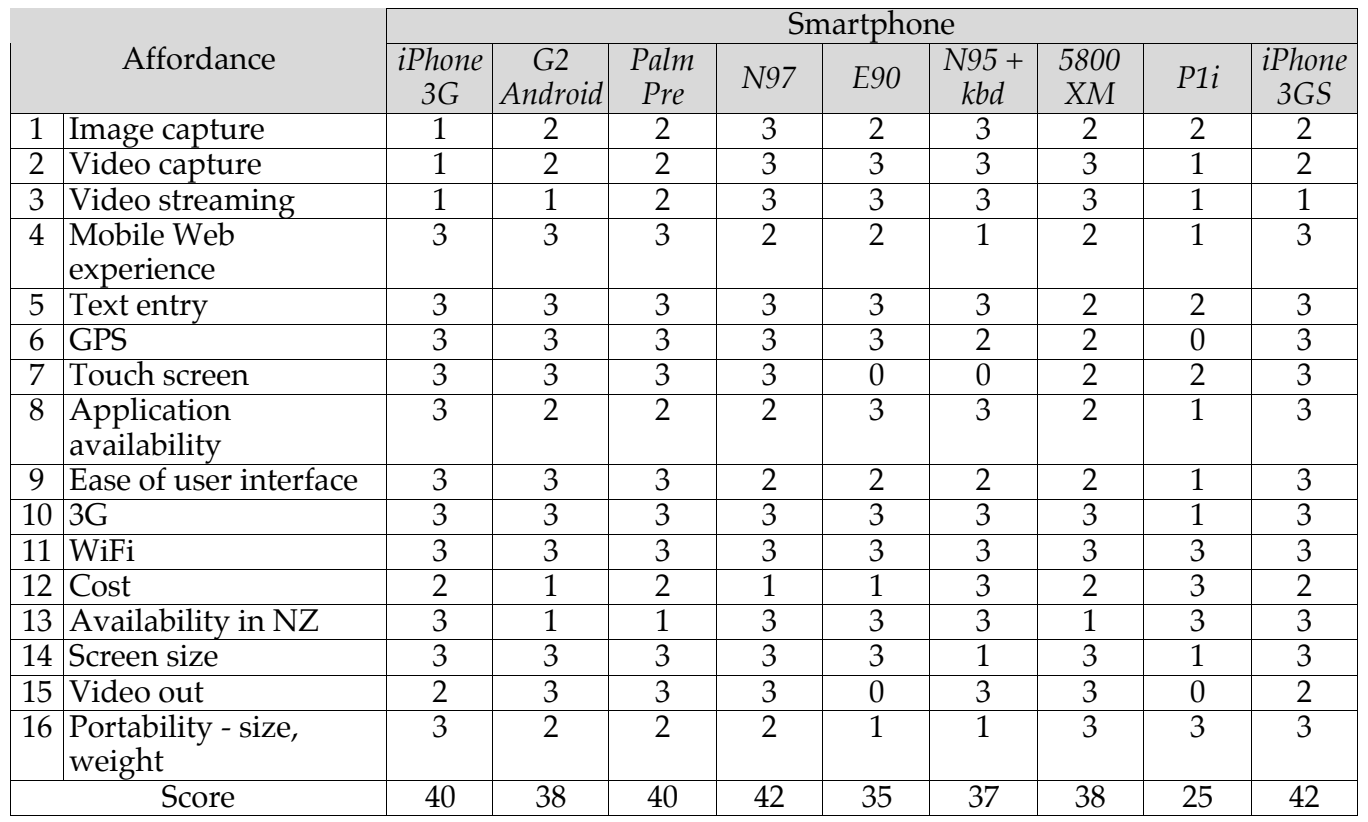

\section{M-learning journeys}

The following section outlines student and lecturer feedback on the impact of the integration of mobile Web 2.0 into their respective courses, and how this has changed over the period of the projects (in some cases this spans 1, 2, 3 or even 4 years). Compilations of student and staff and student vodcasts (online video recordings) are collated on YouTube, giving a visual, multimedia overview of each different m-learning 'journey'.

\section{M-learning project summaries}

- (2008) http: / / www.youtube.com/watch?v=8Eh5ktXMji8

- (2008) Slideshow http:/ / www.youtube.com/watch?v=RRPD8_WexeQ

- (2009) http:/ / www.youtube.com/watch?v=xFBfBflzTw0

Diploma of Landscape Architecture (2006 to 2009)

- (2006) Lecturer as participant in first COP http: / / www.youtube.com/watch?v=jn0HBIkF_U

- (2006) Lecturer presenting after finish of COP http: / / www.youtube.com/ watch?v=kUuJ-gW_vuc

- (2007) Lecturer overview of project http: / / www.youtube.com/watch?v=CBWkRrG7-xo

- (2008) Participant reflections http:/ / nz.youtube.com/ watch?v=c8IZSVtaMmM

- (2009) Community of practice http:/ / www.youtube.com/watch?v=znGpF1SXx9k

- (2009) Project introduction http:// www.youtube.com/watch?v=Wlfhyw_Pq5M 
- (2009) Lecturer1 reflections

http:// pennycliffin.vox.com/library/post/minisymposium.html

- (2009) Lecturer2 reflections http:/ / www.youtube.com/watch?v=j9rK9VKR11Y

The 2006 development of the lecturer COP formed the foundation of the intentional COP model for supporting the successive projects. The iterations of the Landscape Design m-learning project illustrate the disruptive nature of mobile Web 2.0, disrupting the traditional course pedagogies and student expectations. They also illustrate the critical nature of proper technology support for the participants.

Bachelor of Product Design (2006 to 2009)

- (2007) Lecturer presents blogging project http: / / www.youtube.com/watch?v=90ORtMXVW2M

- (2007) Lecturer COP http:// www.youtube.com/watch? $v=j z n H f b 8 d s v s$

- (2008) Third Year students' reflections http: / / www.youtube.com/watch? $v=V 5$ co1cdzfik

- (2008) Third Year participants reflections http: / / www.youtube.com/ watch?v=d44q77cz7H4

- (2008) Student productivity enhanced http:/ / www.youtube.com/watch? $\mathrm{v}=\mathrm{n} 0 \mathrm{~m} 2 \mathrm{rO}-\mathrm{LzKQ}$

- (2008) HOD reflections http:/ / www.youtube.com/watch?v=0H8AvrrHQuQ

- (2008) Third Year student presents project http: / / www.youtube.com/ watch?v=u2GYwKSby1k

- (2008) First Year student reflections http: / / www.youtube.com/watch?v=8QUfw9_sFmo

- (2008) Second Year student reflections http: / / www.youtube.com/watch?v=6jwAFXBZAz0

- (2008) Project overview http://www.youtube.com/watch?v=8Eh5ktXMji8

- (2008) End of 2008 project http:/ / www.youtube.com/watch?v=091eCF3mB44

- (2009) Introducing the project http:/ / www.youtube.com/watch?v=dTT_cjjlQXk

- (2009) Introduction of First Year project http:/ / www.youtube.com/watch? $=$ Z6wN36H4TNo

- (2009) First Year initial smartphone reflections http: / / www.youtube.com/watch?v=9WMZD5kNGAI

- (2009) Second Year student use of moblogging and Google Docs

- (2009) Third Year COP http:/ / www.youtube.com/watch?v=4ReV7GAxd0A

- (2009) Third Year project overview http:/ / www.youtube.com/watch?v=uDO0Er7tL54

- (2009) Third Year lecturer reflection http:/ / www.youtube.com/watch?v=mmTI7F_2tiU

- (2009) Third Year N97 rollout http:/ / www.youtube.com/watch?v=atq9ZjnDUDE

The Product Design m-learning project iterations have illustrated the potential to transform traditional teaching approaches and introduce context bridging teaching and learning scenarios via mobile Web 2.0.

Diploma of Contemporary Music (2008 to 2009)

- (2008) Project Overview http:/ / www.youtube.com/watch?v=IXUekj8c86k

- (2008) Student Reflections http://nz.youtube.com/watch?v=0It5XUfvOjQ

- (2008) Lecturer1 Reflections http:// www.youtube.com/watch?v=g52Jv_LmDbk 
- (2008) Lecturer2 Reflections http:/ / www.youtube.com/watch?v=dKkaaKyrtQE

- (2009) Project Summary http:/ / www.youtube.com/watch?v=hLNNTK1_wGQ

- (2009) Lecturer2 Reflections http:/ / www.youtube.com/watch?v=o9p4i23CsPE

- (2009) Student Reflections http://www.youtube.com/watch?v=5wbryYTmW88

The Contemporary Music m-learning project iterations have illustrated the critical nature of integration of mobile Web 2.0 into the course curriculum and assessment.

Bachelor of Performing and Screen Arts (2009)

- Lecturer COP http:/ / www.youtube.com/watch?v=y3x4Bzm-RbY

- (2009) Quick poll of students pre project http:/ / www.youtube.com/watch?v=8YugBJz4-no

- Rollout of XM5800 and netbooks to students http:/ / www.youtube.com/watch?v=Ct5iBSz8ai4

- Example lecturer use of QIK video streaming http://www.qik.com/miltonjustice

- Example lecturer use of GoogleTalk http: //www.youtube.com/watch?v=oQM9kOBpDEk

Bachelor of Architecture (2009)

- Lecturer COP http:/ / www.youtube.com/watch?v=cj20YUisVBM

- Introduction of project to students http: / / www.youtube.com/watch?v=QMYtcx1gvxg

- Rollout of XM5800 and netbooks to students http:/ / www.youtube.com/watch?v=wemy0BDD1eE

The Performing and Screen Arts and the Architecture projects are still in early stages; however early indications are they are highlighting the critical nature of lecturer acceptance and development of mobile Web 2.0 capability. Comparing and contrasting the various m-learning contexts provides rich data for drawing out transferable implementation principles. Below we explore further two participant scenarios from the Product Design projects.

\section{Example m-learning scenarios}

Dan's story: A student's mobile Web 2.0 experience (2008 to 2009).

During the second semester of 2008, third year Bachelor of Product Design student Dan decided to use the smartphone's camera to record still images and video podcasts outlining significant and iterative steps in his negotiated major project design process when designing a snow kite harness. This allowed students to reflect and critique their design work and design methodology using visual media rather than simply creating a text-based book or online journal. This took place over the six-month product design project. Video clips were recorded on the N95 from the design studio on campus, from testing in the local park, and from test flights during two ski-field trips in the South Island of New Zealand. The course lecturers followed Dan's blog posts, offering tips and design guidance while on campus, at home, and while attending overseas conferences. The video clips were later edited and compiled into a ten-minute video overview of the most significant design steps taken over the course of the design project. The compilation video was then uploaded to YouTube and the student's blog for showcasing and sharing. Upon graduation, Dan continued to use his blog to track 
the further development of his major project through to commercialisation. Via his blog Dan was able to regularly and easily update all of the stakeholders now involved in his project.

Without the mobile technology I would have had to do a lot more writing, and because I don't like writing I suspect I would have skipped out a lot of my ideas - I have a lot of ideas and then I either discard or include them, and that's something I'm learning as a designer is to document my thought processes, its part of the design process so you can reflect on your decisions. So I found with the mobile technology, being able to pick up the phone, turn it on, video myself talking to it like it was a diary, sort of Captain Kirk style, that I can actually use the design processes that other people write, easier to do. So it made it easier for me to video my thoughts and feelings about the project (Third year Product Design student, Dan, 2008).

- Compilation of Dan's vodcasts (2008)

http:/ / www.youtube.com/watch?v=Y4QEvQURWtc

- Dan presenting to 2009 students http://www.youtube.com/watch?v=TSzPgeNDDBY

Roger's story: A lecturer's mobile Web 2.0 journey (2006 to 2009).

As a faculty staff member who comes from a creative industries background that is mostly immersed in a standard, studio teaching model, Roger has witnessed a number of benefits for mobile Web 2.0 technologies to enhance teaching and learning. The standard studio teaching environment of one communal space and one timetable is unlikely to offer the best support and learning opportunities for todays creative students; it does not mirror the 'real contemporary world'. Mobile web 2.0 technology allows for a shift away from the default studio environment to a new more fluid and dynamic situation. Utilising mobile Web 2.0 has disrupted the timetabled, studio learning environment and has placed the student groups into a social constructivist framework. The m-learning trials required Roger to develop a set of new skills and attitudes. Initially this proved to be uncomfortable and time consuming. However, as he immersed himself into the initial trial, the obvious benefits for teaching and learning he encountered convinced him to continue.

The chief benefits noted are increased interaction between students, increased interaction from external, non-timetabled commentators, and the development of student reflective journals. Clients have been able to track projects in the making, add comments and steer students, if need be. At final presentations, clients have arrived 'knowing' the projects and can engage deeply on the project's outcomes and validity. Student blogs have effectively become online reflective journals. Design students often struggle to document their design process and methodologies and as a result, can find it hard to remember how they arrived at their end result. The use of blogs has created a 'bread crumb' trail that students and staff can go back to, both during and after the project, to check their working.

Roger has witnessed an increased engagement in the course from students when using mobile Web 2.0 technology. With each project over the last 3 years the initial 10-14 day period of the projects sees a drop off in 'normal' project activity. This is due to the newness of the tools used, the setting up of the software and hardware, and the fun students have exploring the new technology made available to them. The increased engagement from students using mobile Web 2.0 comes from a sense of connectivity via immediate access to the Internet, photo sharing, IM, emailing and the usual phone 
and txt messaging the WMDs bring. Students often group together looking at online material, and send each other files and photos, URLs and other digital information. Video blogging has become a favourite activity and is an effective way to get out of studio information across in a short space of time. There is also a sense of current technology being embedded into the learning experience. Finally, students' editorial skills have increased due to the constant need to monitor the content of their blogs.

The trials have shown that there are key issues to confront if mobile Web 2.0 is to be successfully integrated into courses. The issues include assessment and staff participation, staff blogging and professional development, and technology choices and support. Projects that do not carry an assessment weighting see a slower and lower uptake. Students want to receive credit for doing something that takes time, focus and commitment. It is vital that staff participate in the blogging process and run their own blogs alongside the student ones. Students want to see that staff are visiting their blogs and commenting on posts as well as offering information that might assist them with their projects. This doesn't mean staff are required to comment on all posts, but reading the blogs is important.

Our projects have allowed students to have the WMDs free of charge. This ensured that participants had the tools they needed to work effectively. A regular technology update is also required and we have found that the most effective way for this to occur is in a community of practice form with participation from a technology steward. Over the last 3 years, the introduction of mobile Web 2.0 tools into the Bachelor of Product Design has facilitated significant flexibility for students allowing them to stay connected, share their ideas widely, participate in world wide creative communities, and choose to work in virtually any context on and off campus.

\section{Reflective vodcasts illustrating Roger's m-learning journey}

- Roger presenting blogging project (2007) http: / / www.youtube.com/ watch?v=90ORtMXVW2M

- Lecturer COP (2007) http: / / www.youtube.com/watch? v=jznHfb8dsvs

- Design Symposium presentation (2008) http: / / www.youtube.com/watch?v=Fy_rxIqEAFs

- IADIS Conference (2009) http:/ / www.youtube.com/watch?v=QGdmswcbAGs

- IADIS Conference reflection (2009) http:/ / www.youtube.com/watch?v=2f0naWez6g

- Roger presenting at minisymposium http: / / www.youtube.com/watch?v=9HV7Yh3JLss

\section{Discussion}

The various m-learning trials undertaken have illustrated that pedagogical integration of m-learning into a course or curriculum requires a paradigm shift on behalf of the lecturers involved, and this takes significant time. Hameed (2009) describes this process as a "cultural re-alignment". Many of the identified m-learning scenarios were serendipitous rather than planned by the lecturers. Students also require significant time to gain the skills required to maximise the potential of new and emerging Web 2.0 tools - as our pre-trial surveys indicated, few students were already using these tools for their own content creation before the trial. Immersing students within a social constructivist pedagogical environment can be a new and challenging experience for 
the students, therefore implementation requires planned staging and scaffolding to support student learning (Cochrane, 2009).

Based upon these experiences, in order to achieve an explicit move to a social constructivist learning environment using mobile Web 2.0 tools during 2009, a staged and scaffolded approach has been adopted (Table 3). This staged approach allows the bridging of the PAH (pedagogy, andragogy, heutagogy) continuum (Luckin, et al., 2008), and the embedding of mobile Web 2.0 affordances that support each stage. Additionally, as the life span of mobile computing is generally shorter than that of desktop computing, a staged rollout of WMD computing for students involved in three year long courses could be achieved to minimise the redundancy of the student owned WMDs. Academic staff development is critical in facilitating the pedagogical focus of this rollout.

Table 3: Example m-learning rollout timeframe

\begin{tabular}{|l|l|l|}
\hline \multicolumn{1}{|c|}{ Deliverable } & \multicolumn{1}{|c|}{ Timeframe } & \multicolumn{1}{c|}{ Outcome } \\
\hline $\begin{array}{l}\text { Establish weekly COP with } \\
\text { lecturers and technology steward. } \\
\begin{array}{l}\text { Establish support requirements } \\
\text { (with IT Services and telco). }\end{array}\end{array}$ & $\begin{array}{l}\text { Staff develop competency with m- } \\
\text { learning. } \\
\text { Staff develop pedagogical m-learning } \\
\text { activities based on social constructivist } \\
\text { pedagogies. }\end{array}$ \\
\hline $\begin{array}{l}\text { M-learning projects with staff and } \\
\text { students. } \\
\text { Implementation of the m-learning } \\
\text { activities within each course and } \\
\text { assessment. }\end{array}$ & $\begin{array}{l}\text { Increased student engagement. } \\
\text { Flexible delivery. } \\
\text { Facilitating social constructivist } \\
\text { pedagogies and bridging learning } \\
\text { contexts. }\end{array}$ \\
\hline $\begin{array}{l}\text { Staff publish and present case } \\
\text { studies based on project } \\
\text { implementation. }\end{array}$ & $\begin{array}{l}\text { End of Semester 2 } \\
\text { and beginning of } \\
\text { Semester 3 }\end{array}$ & symposia presentations. \\
\hline
\end{tabular}

A staged integration of m-learning (mobile Web 2.0) across the three years of a program could be structured as shown in Table 4 below.

Based on the experiences gathered from fifteen mobile learning trials over the last three years, the researchers have short listed a number of pedagogical critical success factors:

1. The level of pedagogical integration of the technology into the course criteria and assessment.

2. The level of lecturer modelling of the pedagogical use of the tools.

3. The use of regular formative feedback from both lecturers and student peers.

4. Appropriate choice of mobile devices and software.

5. Technological and pedagogical support.

Therefore the integration of the mobile Web 2.0 technologies into lecturers' daily workflow and integration into course activities and assessment are critical success factors, as is the establishment of a collaborative learning environment. An intentional community of practice model (Langelier, 2005) has been found to be effective for guiding and supporting the mlearning rollout. This comprises weekly "technology sessions" (community of practice) with small groups of lecturers, facilitated by an appropriate 'technology steward' (Wenger, White, Smith \& Spa, 2005). Taking ideas from Herrington's m-learning implementation plan (Herrington, Herrington, Mantei, 
Olney, \& Ferry, 2009), participants of the m-learning COP are required to commit to the following:

\section{Lecturers' requirements for an m-learning rollout}

1. Participation in a weekly community of practice.

2. Personalised integration of mobile Web 2.0 technologies.

3. Development of m-learning activities based on social constructivist pedagogy for students.

4. Implement a semester-long m-learning project with students.

5. Publish a research output based on the project.

Table 4: Scaffolding the rollout of mobile Web 2.0 throughout various course levels

\begin{tabular}{|c|c|c|c|c|c|}
\hline Stage & $\begin{array}{c}\text { Web } 2.0 \\
\text { tools }\end{array}$ & $\begin{array}{c}\begin{array}{c}\text { M-learning } \\
\text { tools }\end{array} \\
\end{array}$ & $\begin{array}{c}\text { Student course } \\
\text { related costs }\end{array}$ & $\begin{array}{c}\text { Course } \\
\text { timeframe }\end{array}$ & $\begin{array}{c}\text { PAH } \\
\text { alignment }\end{array}$ \\
\hline $\begin{array}{l}\text { Level } \\
1\end{array}$ & $\begin{array}{l}\text { Social } \\
\text { collaboration } \\
\text { with peers and } \\
\text { lecturer. Student } \\
\text { generated } \\
\text { content. }\end{array}$ & $\begin{array}{l}\text { Use of student- } \\
\text { owned netbook or } \\
\text { mid-range smart- } \\
\text { phone, LMS and } \\
\text { basic Web } 2.0 \text { sites }\end{array}$ & $\begin{array}{l}\text { Netbook } \$ 700 \\
\text { Internet paid access } \\
\$ 250\end{array}$ & $\begin{array}{l}1 \text { year certif- } \\
\text { icate } \\
\text { programs, or } \\
\text { first year of } \\
\text { longer } \\
\text { programs }\end{array}$ & Pedagogy \\
\hline $\begin{array}{l}\text { Level } \\
2\end{array}$ & $\begin{array}{l}\text { Social collabora- } \\
\text { tion with peers } \\
\text { and 'authentic } \\
\text { environments'. } \\
\text { Context aware }\end{array}$ & $\begin{array}{l}\text { Student owned } \\
\text { laptop and/or } \\
\text { mid-range } \\
\text { smartphone }\end{array}$ & $\begin{array}{l}\text { Laptop cost } \$ 750(\$ 1500 \\
\text { spread over } 2 \text { years) } \\
\text { and/or smart-phone } \\
\$ 750 . \text { Internet paid } \\
\text { access } \$ 250\end{array}$ & $\begin{array}{l}\text { Second year of } \\
\text { two year or } \\
\text { longer } \\
\text { programs }\end{array}$ & $\begin{array}{l}\text { From } \\
\text { pedagogy } \\
\text { to } \\
\text { andragogy }\end{array}$ \\
\hline $\begin{array}{l}\text { Level } \\
3\end{array}$ & $\begin{array}{l}\text { Context } \\
\text { independent. } \\
\text { Student } \\
\text { generated } \\
\text { contexts. } \\
\end{array}$ & $\begin{array}{l}\text { Student owned } \\
\text { laptop and/or } \\
\text { high end } \\
\text { smartphone }\end{array}$ & $\begin{array}{l}\text { Laptop cost } \$ 750(\$ 1500 \\
\text { spread over } 2 \text { years) } \\
\text { and/or smartphone } \\
\$ 750 . \text { Internet paid } \\
\text { access } \$ 250\end{array}$ & $\begin{array}{l}\text { Third year of } \\
\text { program }\end{array}$ & $\begin{array}{l}\text { From } \\
\text { andragogy } \\
\text { to } \\
\text { heutagogy }\end{array}$ \\
\hline
\end{tabular}

\section{Conclusions}

The paper has presented a summary of the pedagogical affordances of smartphones in tertiary education, illustrated by 4 years of research, resulting in an example mlearning implementation plan that is informing future projects. These may be useful as guidelines for other institutions seeking to investigate and implement m-learning.

\section{References}

Cochrane, T. (2006). Learning with wireless mobile devices and social software. In Who's Learning? Whose technology? Proceedings ascilite Sydney 2006.

http: / / www.ascilite.org.au/conferences / sydney06/proceeding/pdf_papers/p50.pdf

Cochrane, T. (2007). Moving mobile mainstream: Using communities of practice to develop educational technology literacy in tertiary academics. Paper presented at MLearn 2007 Making the Connections. 6th International Conference on Mobile Learning, 16-19 October, Melbourne. http:/ / ltxserver.unitec.ac.nz/ thom/pdfs/mlearn2007submission1.pdf

Cochrane, T. (2008). Mobile Web 2.0: The new frontier. In Hello! Where are you in the landscape of educational technology? Proceedings ascilite Melbourne 2008.

http: / / www.ascilite.org.au/conferences/melbourne08/procs/cochrane.pdf 
Cochrane, T. (2009). Mobilizing learning: Intentional disruption. Harnessing the potential of social software tools in higher education using wireless mobile devices. International Journal of Mobile Learning and Organisation, 3(4), Special edition: Developing themes in mobile learning, 399-419.

Hameed, K. \& Shah, H. (2009). Mobile learning in higher education: Adoption and discussion criteria. Paper presented at IADIS International Conference on Mobile Learning 2009. http: / / www.mlearning-conf.org/

Hendery, S. (2009). Great gadget, stratospheric price. New Zealand Herald, 9 July, p.B4. [viewed 9 July 2009, verified 7 Jan 2010] http: / / www.nzherald.co.nz/technology / news/article.cfm? c_id $=5 \&$ objectid $=10583290 \&$ pnum $=0$

Herrington, J., Herrington, A., Mantei, J., Olney, I. \& Ferry, B. (Eds.) (2009). New technologies, new pedagogies: Mobile learning in higher education. Wollongong: Faculty of Education, University of Wollongong. http:/ / ro.uow.edu.au/ newtech/

Langelier, L. (2005). Work, learning and networked: Guide to the implementation and leadership of intentional communities of practice. Quebec City: CEFIRO (Recherche et Études de cas collection).

Luckin, R., Clark, W., Garnett, F., Whitworth, A., Akass, J., Cook, J., Day, P., Ecclesfield, N., Hamilton, T. \& Robertson, J. (2008). Learner generated contexts: A framework to support the effective use of technology to support learning. [viewed 5 Nov 2008, verified 7 Jan 2010] http:/ / api.ning.com/files/Ij6j7ucsB9vgb11pKPHU6LKMGQQkR-YDVnxruI9tBGf1Q-eSYUDvMil6uWqX4F1jYA1PUkZRXvbxhnxuHusyL11RXVrBKnO/LGCOpenContextModelning.doc

McLoughlin, C. \& Lee, M. J. W. (2008). Future learning landscapes: Transforming pedagogy through social software. Innovate: Journal of Online Education, 4(5). http://innovateonline.info/pdf/vol4_issue5/Future_Learning_Landscapes_Transforming_Pedagogy_through_Social_Software.pdf

O'Reilly, T. (2005). What is Web 2.0: Design patterns and business models for the next generation of software. [viewed March 2006, verified 7 Jan 2010] http: / / oreilly.com/ web2/ archive/ what-is-web-20.html

Prensky, M. (2005). What can you learn from a cell phone? Almost anything! Innovate, 1(5), http:/ / www.innovateonline.info/pdf/vol1_issue5/What_Can_You_Learn_from_a_Cell _Phone_Almost_Anything!.pdf

Uden, L. (2007). Activity theory for designing mobile learning. International Journal of Mobile Learning and Organisation, 1(1), 81-102.

Wenger, E., White, N., Smith, J. \& Spa, K. R. (2005). Technology for communities. [viewed 14 July 2006] http: / / technologyforcommunities.com/

This article received an Outstanding Paper Award at ascilite Auckland 2009 Conference, gaining the additional recognition of republication in AJET (with minor corrections). The reference for the Conference version is:

Cochrane, T. \& Bateman, R. (2009). Smartphones give you wings: Pedagogical affordances of mobile Web 2.0. In Same places, different spaces. Proceedings ascilite Auckland 2009. http:// www.ascilite.org.au/conferences/auckland09/ procs/cochrane.pdf

Authors: Thomas Cochrane, Te Puno Ako (Centre for Teaching and Learning Innovation) and Roger Bateman, Product Design Unitec New Zealand, Private Bag 92025, Auckland Mail Centre, Auckland 1142, New Zealand. http: / / www.unitec.ac.nz/

Contact author: tcochrane@unitec.ac.nz Web: http: / / ltxserver.unitec.ac.nz/ thom/ 